\title{
TINJAUAN MASHLAHAH TERHADAP PERLINDUNGAN SENI UKIR MELALUI INDIKASI GEOGRAFIS
}

\author{
Ahmad Khamim Jazuli \\ Fakultas Syariah UIN Maulana Malik Ibrahim Malang \\ Email: iluzajhamim@gmail.com
}

\section{Abstrak}

Many regions in Indonesia that have produced and preserved the art of carving, but not all have been registered and protected. Carving, usually protected by copyright. But, Jepara Carved Furniture have gained protection through Geographical Indications Certificate. In Indonesia there are regulations related to Geographical Indications as a legal protection, but in the study of Islamic law there is no specific explanation or regulation about geographical indication which may bring the benefit to the community or even bring madhorot, considering the purpose of Islamic law is the welfare of human life both spiritual and material, individual or social.

Banyak daerah di Indonesia yang memproduksi dan melestarikan seni ukir, namun tidak semua didaftarkan dan mendapatkan perlindungan. Biasanya seni ukir dilindungi melalui hak cipta. Namun, ternyata Mebel Ukir Jepara telah mendapatkan perlindungan melalui sertifikat Indikasi Geografis. Di Indonesia sudah ada pengaturan terkait Indikasi Geografis sebagai payung bukumnya, namun dalam kajian bukum Islam belum ada penjelasan atau pengaturan yang spesifik mengenai Indikasi Geografis yang mungkin bisa mendatangkan kemaslahatan bagi masyarakat atau malah membawa madhorot, mengingat tujuan dari bukum Islam adalab kemaslahatan hidup manusia baik rohani maupun jasmani, individual atau sosial. Penelitian ini adalah penelitian normatif(library research). Pendekatan yang digunakan adalab pendekatan konseptual (conceptual approach). Dalam penelitian ini metode analisis bahan bukum yang digunakan adalah analisis deskriptif kualitatif.

Keywords: the art of carving, Maslahah, geographical indication 


\section{Pendahuluan}

Biasanya Seni Ukir termasuk dalam pembahasan hak cipta. Namun Seni Ukir Jepara didaftarkan ke Direktorat Jenderal Hak kekayaan Intelektual dan mendapatkan sertifikat Indikasi Geografis Mebel Ukir Jepara. Awal mulanya produk industri desain ukir Jepara berhasil masuk perdagangan internasional dan mendapatkan apresiasi yang positif dari konsumen di negara lain dan mampu menarik investor asing untuk menanamkan modal usaha di Jepara. Sampai pada akhirnya timbul permasalahan. PT. Horrison, perusahaan milik orang Inggrismembuat katalog yang memuat gambar-gambar desain ukiran Jepara dan mendaftarkan katalog tersebut ke Kantor HKI dalam rangka memperoleh perlindungan hak cipta.Namun setelah penyidikan, dinyatakan bahwa Dirjen HKI hanya memberi legalitas/pengesahan pada buku katalog Harrison, bukan content/isi gambargambar di dalam buku. ${ }^{1}$

Untuk mengatasi agar kasus penjiplakan tidak terulang kembali, Pemerintah Kabupaten Jepara mendaftarkan Ukiran Jepara ke Dirjen HKI yang kemudian mendapatkan Sertifikat Indikasi Geografis Mebel Ukir Jepara dengan nomor: IG.00.2007.000005 tentang Mebel Ukir Jepara. ${ }^{2}$

Tujuan hukum Islam adalah kemaslahatan hidup manusia baik rohani maupun jasmani, individual atau sosial, dan kemaslahatan dimaksud tidak hanya di dunia saja namun juga untuk kehidupan yang kekal di akhirat kelak. ${ }^{3}$ Dalam UU No. 15 Tahun 2001 tentang Merekdan PP No. 51 Tahun 2007 sudah ada pengaturan terkait Indikasi Geografis, namun dalam kajian hukum Islam belum ada pengaturan mengenai Indikasi Geografis. Dengan adanya Indikasi Geografis yang diberikan terhadap seni ukir akankah mendatangkan kemaslahatan bagi masyarakat atau malah membawa madhorot. Maka yang menarik untuk diteliti yaitu seperti apakah tinjauan mashlahah terhadap perlindungan seni ukir melalui Indikasi Geografis.

\section{Pengertian Indikasi Geografis}

Konsep perlindungan Hak Atas Kekayaan Intelektual pertama kali berasal dari Eropa yang mempunyai budaya individualistis dan kapitalis. Indonesia telah meratifikasi TRIPs melalui keanggotaan WTO, sehingga secara yuridis Indonesia

1 http://ncexvero.blogspot.co.id/2014/06/kasus-haki-jepara-jawa-tengah.html, diakses pada tanggal 11 April 2016.

2 Farisa Adila, "Hak Indikasi Geografis Mebel Ukir Jepara (IG MUJ) dalam Peningkatan Ekonomi Daerah Kabupaten Jepara", (Online), (https://www.academia.edu/10110570/Hak Indikasi Geografis Mebel Ukir_Jepara_IG_MUJ_dalam_Peningkatan_Ekonomi_Daerah_Kabupaten_Jepara, diakses pada tanggal 27 Maret 2016), 2016. pukul 05.27.

3 Ikrar, Paradigma Hukum Islam dan Problematika Penerapannya (Malang: UM Press, 2012), h. 65. 
juga terikat dengan perlindungan HKI sebagaimana yang diatur dalam TRIPs. ${ }^{4}$ Indikasi geografis di Indonesia diatur melalui UU No. 15 Tahun 2001 tentang Merek Jo PP Nomor 51 Tahun 2007 Tentang Indikasi Geografis. Indikasi Geografis berdasarkan persetujuan TRIPs adalah tanda yang mengidentifikasikan suatu wilayah negara anggota, atau kawasan atau daerah di dalam wilayah tersebut sebagai asal barang, di mana reputasi, kualitas dan karakteristik barang yang bersangkutan sangat ditentukan oleh faktor geografis tersebut. Berdasarkan ketentuan tersebut dapat dimengerti bahwa asal suatu barang (tentu saja sebenarnya termasuk jasa) yang melekat dengan reputasi, karakteristik dan kualitas suatu barang yang dikaitkan dengan wilayah tertentu dilindungi secara juridis. ${ }^{6}$

Adapun pengertian lain mengenai Indikasi Geografis adalah suatu tanda yang menunjukkan daerah asal suatu barang, yang karena faktor lingkungan geografis termasuk faktor alam, faktor manusia atau kombinasi dari kedua faktor tersebut, memberikan ciri dan kualitas tertentu pada barangyang dihasilkan. ${ }^{7} \mathrm{Ciri}$ dan kualitas suatu barang yang dipelihara dan dipertahankan dalam jangka waktu tertentu akan melahirkan reputasi (keterkenalan) atas barang tersebut, yang selanjutnya memungkinkan barang tersebut memiliki nilai ekonomi tinggi. Karena itu barang tersebut perlu mendapatkan perlindungan hukum yang memadai. ${ }^{8}$

\section{Pengertian Seni Ukir/Ukiran ${ }^{9}$}

Ukiran merupakan gambar hiasan dengan bagian-bagian cekung (kruwikan) dan bagian-bagian cembung (buledan) yang menyusun suatu gambar yang indah. Pengertian ini berkembang hingga dikenal sebagai seni ukir yang merupakan seni membentuk gambar pada kayu, batu, atau bahan-bahan lain.

Di Indonesia ada beberapa motif ukiran yang sangat beraneka ragam coraknya,antara lain: motif Pajajaran, Mataram, Majapahit, Jepara, Pekalongan, Madura, Cirebon, Surakarta, Yogyakarta, Bali, dan juga Semarang. Dari beberapa motif tersebut memiliki ciri-ciri yang membedakan satu motif dengan motif yang lainnya.

4 Khoirul Hidayah. Tingkat Pemahaman Mahasiswa tentang Perlindungan Hak Cipta Atas Karya Tulis (Studi Terhadap Mahasiswa UIN Maulana Malik Ibrahim Malang). De Jure. Vol. 5 No. 1 (2013)

5 Khoirul Hidayah. Hukum Hak Kekayaan Intelektual di Indonesia (Kajian UU dan Integrasi Islam). h.69.

6 OK. Saidin. Aspek Hukum Hak Kekayan Intelektual (Intellectual Property Rights), h. 386.

7 Adrian Sutedi, Hak Atas Kekayaan Intelektual, h. 151.

8 Penjelasan Pasal 1 Peraturan Pemerintah Nomor 51 Tahun 2007 tentang Indikasi Geografis

9 Ahmad Wahyudi,Rancang Bangun Sistem Informasi Industri Mebel Ukir Jepara Berbasis Web (Malang: Jurusan Teknik Informatika Fakultas Sains Dan Teknologi Universitas Islam Negeri Maulana Malik Ibrahim, 2010), h. 8. 


\section{Pengertian Mashlahah}

Secara etimologi, mashlahah berasal dari bahasa Arabyang berarti manfaat, faedah, bagus, guna atau kegunaan. Kata mashlahah merupakan bentuk masdar

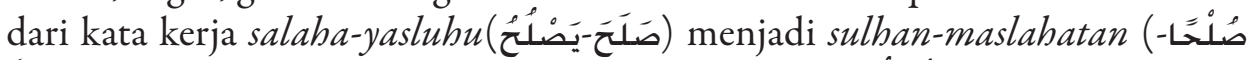

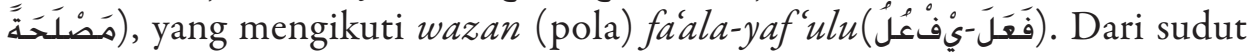
pandang ilmu sorof (morfologi), kata mashlahah satu wazan (pola) dengan kata manfáah (مَنَفَ). Kedua kata ini (mashlahah dan manfáah) telah di-Indonesiakan menjadi maslahat dan manfaat.'

Kemudian secara terminologi, mashlahah diartikansebagai kemanfaatan yang dikehendaki oleh Allah untuk hamba-hambanya, baik berupa pemeliharaan agama mereka, pemeliharaan jiwa/diri mereka, pemeliharaan kehormatan diri serta keturunan mereka, pemeliharaan akal budi mereka, maupun berupa pemeliharaan harta kekayaan mereka. ${ }^{11}$

\section{Pembagian Mashlahah}

Para ulama ushul fiqh membagi mashlahah menjadi beberapa macam dilihat dari beberapa segi bentuk sebagai berikut:

a. Sebagian ulama ada yang membagi mashlahah berdasarkan tujuan zamannya terbagi menjadi dua tingkatan, yaitu: ${ }^{12}$

(1) Mashlahah dunia adalah kewajiban atau aturan syara' yang terkait dengan hukum-hukum muamalah (interaksi sosial dan ekonomi).

(2) Mashlabah akhirat adalah kewajiban atau aturan syara' yang terkait dengan hukum-hukum tentang aqidah (tauhid) dan ibadah (mahdlab/murni).

b. Dilihat dari segi kualitas dan kepentingan kemaslahatan, dibagi menjadi tiga bagian yaitu :

(1) Mashlahah al-dharuriyah, adalah kemaslahatan yang berhubungan dengan kebutuhan pokok umat manusia di dunia dan di akhirat. Dalam hal ini Allah melarang murtad untuk memelihara agama; melarang membunuh untuk memelihara jiwa; melarang minumminuman keras untuk memelihara akal; melarang berzina untuk memelihara keturunan; dan melarang mencuri untuk memelihara harta. ${ }^{13}$

(2) Mashlahahal-hajiyyah yaitu kemaslahatan yang dibutuhkan dalam

10 Asmawi, Perbandingan Ushul Figh, (Jakarta: Amzah, 2011), h.127.

11 Asmawi, Perbandingan Ushul Fiqih, h.128

12 Abbas Arfan, "Maslahah dan Batasan-Batasannya Menurut Al-Bûthî (Analisis Kitab Dlawabith alMashlahah Fi al-Syarĩah al-Islamiyyah)," h. 92.

13 Amir Syarifuddin, Ushul Fiqh 2, h. 371. 
menyempurnakan kemaslahatan pokok sebelumnya yang berbentuk keringanan untuk memepertahankan dan memelihara kebutuhan mendasar manusia. Semuanya ini disyariatkan Allah untuk mendukungkebutuhan mendasaral-mashlihal-khamsah.Mashlahah al-hajjiyah sering disebut kemaslahatan sekunder. Dengan kata lain, jika tingkat kemaslahatan sekunder ini tidak tercapai, manusia akan mengalami kesulitan memelihara agama, jiwa, akal, keturunan, dan harta mereka. ${ }^{14}$

(3) Mashlahah al-tabsiniyyah adalah kemaslahatan yang sifatnya pelengkap berupa keleluasaan yang dapat melengkapi kemaslahatan sebelumnya. Atau mashlahah yang kebutuhan hidup manusia kepadanya tidak sampai tingkat daruri, juga tidak sampai tingkat hajjiyah, namun kebutuhan tersebut perlu dipenuhi dalam rangka memberi kesempurnaan dan keindahan bagi hidup manusia. Apabila kemaslahatan ini tidak tercapai, manusia tidak sampai mengalami kesulitan memelihara kelima unsur pokoknya, tetapi mereka dipandang menyalahi nilai-nilai kepatutan, dan tidak mencapai taraf hidup bermartabat. ${ }^{15}$

c. Dilihat dari segi kandungan mashlahah dibagi menjadi:

(1) Mashlahah al-mmah, yaitu kemaslahatan umum yang menyangkut kepentingan orang banyak. Kemaslahatan umum itu tidak berarti untuk kepentingan semua orang, tetapi bisa berbentuk kepentingan mayoritas umat atau kebanyakan umat. ${ }^{16}$

(2) Mashlahah al-khshshah, yaitu kemaslahatan pribadi dan ini sangat jarang sekali, seperti kemaslahatan yang berkaitan dengan pemutusan hubungan perkawinan seseorang yang dinyatakan hilang (mafqud). ${ }^{17}$ Kemaslahatan pribadi atau perseorangan tetap dihargai selama tidak bertentangan dengan kemaslahatan umum. ${ }^{18}$

d. Dilihat dari segi berubah atau tidaknya mashlahah dibagi menjadi:

(1) Mashlahah al-tsbitah adalah kemaslahatan yang tidak pernah mengalami perubahan dan bersifat tetap sampai akhir zaman. Kemaslahatan ini bersifat tetap walaupun waktu, lingkungan, dan orang-orang yang berhadapan dengan kemaslahatan tersebut telah

14 Abd. Rahman Dahlan, Ushul Figh, h.310.

15 Abd. Rahman Dahlan, Ushul Figh, h.311.

16 Nasrun Haroen, Ushul Figh I, (Jakarta: Logos Wacana Ilmu, 1997), h. 116.

17 Nasrun Haroen, Ushul Figh I, h. 116.

18 Teungku Muhammad Hasbi Ash Shiddieqy, Falsafah Hukum Islam, (Semarang: PT. Pustaka Rizki Putra, 2001), h. 181. 
berubah. $^{19}$

(2) Mashlahah al-mutaghayyirah adalah al-mashlahah yang mengalami perubahan sejalan dengan perubahan waktu, atau lingkungan, dan atau orang-orang yang menjalaninya. Hal ini dapat terjadi hanya pada masalah-masalah yang berkaitan dengan muamalah dan kebiasaan $\left(\right.$ al-'urf). ${ }^{20}$

e. Dilihat dari segi keberadaan mashlahah menurut syara' dibagi:

Mashlabah mu'tabarah adalah kemaslahatan yang didukungoleh syara’ Maksudnya adanya dalil khusus yang menjadi dasar bentuk dan jenis kemaslahatantersebut. ${ }^{21}$ Perhatian atau dukungan syara' itu ada dalam dua bentuk, yaitu: ${ }^{22}$ a) dukungan langsung dalam arti nash atau ijma' secara langsung menetapkannya untuk diperhatikan. Mashlahah dalam bentuk ini disebut al-muatstsirah; b) perhatian atau dukungan tidak langsung, dalam arti memang tidak ada nash atau ijma' yang memperhatikan atau mendukung mashlahah yang didasarkan pada akal itu, tetapi nash atau ijma' yang memperhatikan dan mendukung terhadap hal lain yang sejenis dengan itu. Mashlahah dalam bentuk ini disebut al-mulimah.

(1) Mashlahah al-mulghah adalah kemaslahatan yang ditolak oleh syara', karena bertentangan dengan ketentuan syara. ${ }^{23}$

(2) Mashlahah al-mursalah adalah memelihara maksud syara' dengan jalan menolak segala yang merusakkan makhluk. ${ }^{24}$

\section{Pembahasan}

Indonesia memiliki banyak seni ukir yang diproduksi di beberapa daerah seperti Bali, Cirebon dan Jepara yang masing-masing memiliki ciri dan karakteristik yang khas. Eksistensi seni ukir di Indonesia harus mendapatkan perhatian serius agar tidak diklaim oleh bangsa lain seperti yang terjadi pada kebudayaan Indonesia yang lain, misalnya Reog Ponorogo yang pernah diklaim sebagai bagian dari kebudayaan Malaysia. Kasus plagiasi dalam bidang seni ukir sendiri sudah pernah terjadi pada Seni Ukir Jepara yang pada waktu itu belum mendapatkan sertifikat Indikasi Geografis.

Terjadinya klaim atau plagiasi terhadap Mebel Ukir Jepara oleh bangsa asing sebelum memperoleh sertifikat Indikasi Geografis tentu membawa madhorrotbagi Bangsa Indonesia, khususnya bagi para pengusaha dan para pegiat ukir di Kabupaten

19 Abd. Rahmad Dahlan, Ushul Figh, h.314.

20 Abd. Rahmad Dahlan, Ushul Figh, h.314

21 Totok Jumantoro dan Samsul Munir Amin, Kamus Ilmu Ushul Fikih, h.206.

22 Amir Syarifuddin, Ushul Figh 2, h. 241.

23 Totok Jumantoro dan Samsul Munir Amin, Kamus Ilmu Ushul Fikih, h.203.

24 Totok Jumantoro dan Samsul Munir Amin, Kamus Ilmu Ushul Fikih, h.203. 
Jepara. Padahal, dalam Islam kemudaratan itu harus dihilangkan. Hal ini tertuang dalam salah satu kaidah fiqh yang menjadi dasar untuk menghilangkan madhorrot, yaitu: الَََّرْريُرَالَ yang artinya "kemudaratan (bahaya) itu harus dihilangkan". Aplikasi kaidah tersebut ialah lebih pada kewajiban menghilangkan madhorrot setelah madhorrot itu ada atau telah terjadi. ${ }^{25}$

Berdasarkan kaidah di atas, apabila telah terjadi madhorrot maka kita diwajibkan untuk menghilangkan madhorrot tersebut. Setelah plagiasi atau klaim yang terjadi pada Mebel Ukir Jepara, maka langkah yang harus ditempuh adalah menghilangkan kemadhorrotan tersebut, yakni dengan mencari perlindungan secara legal formal. Kaitannya dengan Mebel Ukir Jepara, perlindungan bisa diperoleh melalui sertifikat Indikasi Geografis. Dengan adanya sertifikat Indikasi Geografis, Mebel Ukir Jepara akan mendapatkan perlindungan selama ciri dan karakteristik khasnya masih melekat. Begitu pula dengan seni ukir dari daerah yang lain akan terlindungi secara hukum dengan sertifikat Indikassi Geografis. Jadi dapat dikatakan, bahwa adanya Indikasi Geografis Mebel Ukir Jepara dapat menghilangkan madhorrot dan menarik mashlahab bagi semua pihak. Pihak-pihak yang tidak bertanggung jawab tidak akan bisa lagi melakukan klaim atau plagiasi terhadap desain Mebel Ukir Jepara.Hal ini tentu sesuai dengan apa yang yang menjadi tujuan utama dari mashlahah, yaitu: ${ }^{26}$

a. Mendatangkan manfaat kepada umat manusia (jalbu manfáat), baik bermanfaat untuk hidup di dunia, maupun manfaat untuk kehidupan di akhirat.

b. Menghindarkan kemudaratan (daf'u madhorrot), baik dalam kehidupan di dunia, maupun untuk kehidupan akhirat.

Semestinya, Pemerintah Daerah Kabupaten Jepara sudah mendaftarkan Mebel Ukir Jepara ke Dirjen HKI sejak dulu untuk mendapatkan perlindungan hukum sebelum terjadinya kasus plagiasi yang dilakukan oleh bangsa asing. Karena sebenarnya dalam kajian mashlahah, menghilangkan madhorrotjustru harus didahulukan daripada menarik suatu kemaslahatan. Apalah gunanya kemaslahatan jika masih ada madhorrotyang merugikan atau bahkan membahayakan bagi kehidupan manusia. Sehingga kaitannya dengan hal tersebut dalam kaidah fiqh ditetapkan suatu kaidah, yaitu:

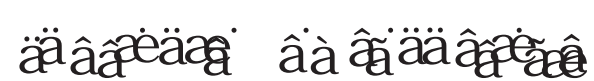

Artinya: "menghilangkan kemafsadatan (madhorrot) harus didahulukan daripada

25 Abbas Arfan, Kaidah-Kaidah Figh Múamalah dan Aplikasinya dalam Ekonomi Islam \& Perbankan Syariah (Jakarta: Direktorat Pendidikan Tinggi Islam Direktorat Jenderal Pendidikan Islam Kementerian Agama Republik Indonesia, 2012), h. 185.

26 Amir Syarifuddin, Ushul Figh 2, h. 233. 
menarik kemaslahatan".

Akan tetapi pada kenyataannya Pemerintah Daerah Kabupaten Jepara baru menyadari hal tersebut pasca terjadinya insiden itu. Namun, lebih baik terlambat daripada tidak berbuat sama sekali. Untuk itulah, agar dapat menjauhkan seni ukir yang ada di Indonesia dari berbagai tindakan yang ilegal atau madhorot yang lain, pendaftaran seni ukir ke Dirjen HKI sangat diperlukan untuk mendapatkan perlindungan melalui Indikasi Geografis. Sehingga kasus yang pernah terjadi pada Mebel Ukir Jepara tidak terjadi pada seni ukir yang lainnya.

Perlindungan hukum terhadap seni ukir seperti yang telah diperoleh Mebel Ukir Jepara melalui pendaftaran Indikasi Geografis, yang ketentuan dan prosedur pendaftarannya diatur oleh undang-undang, menurut penulis merupakan suatu kemaslahatan yang bersifat hakiki, bukan kemaslahatan yang bersifat imajinatif. Karena apabila mempunyai sertifikat Indikasi Geografis, seni ukir akan terhindar dari kemadhorrotan,seperti plagiasi yang pernah terjadi pada Mebel Ukir Jepara, yang merugikan bangsa Indonesia sebab salah satu kekayaan budayanya diklaim oleh bangsa asing. Demikian pula bagi para pengusaha seni ukir yang tentu akan banyak dirugikan karena produk unggulan mereka banyak diproduksi oleh pihak yang tidak berhak. Dengan adanya sertifikat Indikasi Geografis bagi seni ukir berarti menghilangkan madhorrot dan mendatangkan mashlahah yang berupa perlindungan hukum bagi eksistensi seni ukir.

Kemaslahatan yang ada pada perlindungan seni ukir melalui Indikasi Geografis berlaku umum bagi seluruh Bangsa Indonesia terutama bagi pengusaha atau perajin seni ukir di Indonesia. Karena seni ukir adalah warisan budaya Bangsa Indonesia yang tidak hanya dimiliki oleh perorangan saja, melainkan menjadi milik Bangsa Indonesia secara umum, dan khususnya milik Pemerintah daerah dan warga dimana seni ukir itu berada.

Kemaslahatan yang ada pada perlindungan seni ukir melalui Indikasi Geografis tentu sejalan dengan maqshid syariah, dalamhal ini adalah hifz al$m l$ (pemeliharaan atas harta). Karena produk seni ukir merupakan komoditi yang bernilai ekonomis, yang bisa diperjual belikan sehingga termasuk bagian dari harta kekayaan yang patut untuk dilindungi.

Selain itu, desain seni ukir di Indonesiatidak semerta-merta langsung ada, melainkan merupakan buah pikiran atau karya dan hasil kreatifitas nenek moyang di masa lampau. Menghargai serta mengapresiasi produk pemikiran atau karya yang tidak mengandung unsur-unsur kemusyrikan diperbolehkan dalam syariat Islam, misalnya motif ukiran Jepara yang hanya berupa daun, bunga dan buah yang dikreasikan dan dikombinasikan. 
Penjelasan yang tersebut di atas, menurut penulis telah sesuai dengan syaratsyarat ditentukannya mashlahah yang di antaranya adalah sebagai berikut: ${ }^{27}$

a. Bahwa kemaslahatan tersebut bersifat hakiki, bukan bersifat imajinatif dalam arti apabila orang yang berkesempatan dan yang memusatkan perhatian pada itu yakin bahwa membina hukum berdasarkan kemaslahatan tersebut akan dapat menarik manfaat dan menolak madhorrot bagi umat manusia.

b. Kemaslahatan itu hendaknya berlaku umum (universal) bagi orang banyak dan tidak parsial.

c. Hendaknya kemaslahatan itu sejalan dengan maqosidsyariah dan tidak bertentangan dengan nash atau dalil-dalil qath'i. Dengan kata lain, kemaslahatan tersebut sejalan dengan kemaslahatan yang telah ditetapkan syar'i. (ketentuan yang ada ketegasan dalam Al-Qur'an atau sunnah Rasulullah, atau tidak bertentangan dengan ijma'). ${ }^{28}$

Setelah diketahui bahwa perlindungan seni ukir melalui Indikasi Geografis dapat menghilangkan madhorrot yang juga sekaligus di dalamnya terdapat suatu kemaslahatan, maka berikutnya penulis menganalisis mengenai klasifikasi atau pembagian mashlahah yang ada dalam perlindungan seni ukir melalui Indikasi Geografis. Yakni mashlahah yang terkandung dalam perlindungan seni ukir melalui Indikasi Geografis termasuk kategori mashlahah yang bagaimana, karena kategorisasi atau klasifikasi mashlahah meliputi lima aspek, yakni aspek tujuan zamannya, aspek kualitas dan kepentingan, aspek kandungan kemaslahatan, aspek berubah atau tidaknya mashlahah dan yang terakhir aspek keberadaan mashlahabmenurut syara'.

Sebagaimana diketahui bahwa ukiran merupakan gambar hiasan pada kayu, batu, atau bahan-bahan lain. ${ }^{29}$ Desain ini kemudian dipakai dalam berbagai produk untuk menambah nilai estetik, seperti produk mebel kayu misalnya. Produk yang dihiasi dengan ukiran tentu memberi nilai atau harga yang lebih daripada produk polosan. Jadi keberadaan seni ukir tentu sangat berperan dalam penentuan harga dari suatu barang yang diperjual-belikan.

Kemudian, dalam proses produksi sampai penjualan produk seni ukir tentu melibatkan banyak pihak. Begitu pula eksistensi seni ukir bernilai ekonomis dan bisa termasuk dalam kategori harta. Maka dari itu sangat dibutuhkan suatu perlindungan hukum yang dalam hal ini bisa didaftarkan untuk memperoleh

27 Saifudin Zuhri, Ushul Figih Akal Sebagai Sumber Hukum Islam (Yogyakarta: Pustaka Pelajar, 2011), h.102.

28 Satria Effendi, Ushul Figh, (Jakarta: Prenada Media, 2005), h.153.

29 Ahmad Wahyudi,Rancang Bangun Sistem Informasi Industri Mebel Ukir Jepara Berbasis Web, h. 8. 
perlindungan melalui Indikasi Geografis agar bisa terhindar dari plagiasi atau tindakan ilegal yang lain, yang akhirnya menimbulkan persengketaan dan tindak kejahatan ekonomi yang merugikan masyarakat, bangsa dan negara.

Berdasarkan beberapa klasifikasi mashlahah yang dijelaskan oleh para ulama,' penulis menganalisis bahwa perlindungan seni ukir melalui Indikasi Geografis dalam tinjauan mashlahah, jika dilihat dari tujuan zamannya merupakan mashlahah yang termasuk dalam kategori mashlahah dunia, karena di dalamnya terdapat hak dan kewajiban yang terkait dengan hukum-hukum muamalah seperti interaksi sosial dan ekonomi dan tidak terkait dengan hukum-hukum tentang aqidah (tauhid) dan ibadah (mahdlah/murni). Sedangkan dalam muamalah, terdapat asas kemaslahatan hidup, yakni suatu asas yang mengandung makna bahwa hubungan perdata apapun dapat dilakukan, asal hubungan itu mendatangkan kebaikan, berguna dan berfaedah bagi kehidupan pribadi dan masyarakat, meskipun tidak ada ketentuannya dalam al-Qu'ran dan al-Sunnah. ${ }^{30}$

Kemudian jika ditinjau dari dari segi kualitas dan kepentingan kemaslahatan, maka termasukmashlahahyang bersifatdharuriyyat (primer), karena seni ukir merupakan bagian dari kekayaan intelektual yang termasuk dalam kategori harta, yang memerlukan perlindungan hukum sehingga tidak terjadi persengketaan dan tindak kejahatan ekonomi yang dapat merugikan bangsa. Selain itu, dalam masalah harta, Islam jelas-jelas melarang memakan harta secara bathil. Dalam Al-Quran Allah berfingn:

Artinya: "Dan janganlab kamu makan harta di antara kamu dengan jalan yang batil, dan (janganlah) kamu menyuap dengan harta itu kepada hakim, dengan maksud agar kamu dapat memakan sebagian harta orang lain itu dengan jalan dosa, padahal kamu mengetahui."ঋr

Kemudian jika dilihat dari segi kandungan kemaslahatan, perlindungan seni ukir melalui Indikasi Geografis merupakan kemaslahatan umum (mashlahah 'Ammah).Karena pada dasarnya Indikasi Geografis lebih bersifat komunalistik, yakni dimiliki bersama oleh masyarakat. ${ }^{33}$ Seni ukir merupakan kekayaan budaya Bangsa Indonesia, yang tentunya secara umum dimiliki oleh semua rakyat Indonesia, khususnya pemerintah dan warga dimana seni ukir itu berada yang harus dilindungi oleh hukum.

30 Ahmad Wardi Muslich, Fiqh Muamalat (Jakarta: Amzah, 2010), h. 5.

31 QS. Al-Baqarah (2), 188.

32 Ma'had Tahfidh Yanbu'ul Qur'an, Al-Quddus Al-Qur'an dan Terjemahannya (Kudus: CV. Mubarokatan Thoyyibah, 2014), h. 28.

33 Adrian Sutedi, Hak Atas Kekayaan Intelektual, h. 152. 
Selanjutnya, perlindungan seni ukir melalui Indikasi Geografis ditinjau dari segi berubah atau tidaknya mashlahah merupakan mashlahah al-mutaghayyirah (kemaslahatan yang mengalami perubahan sejalan dengan perubahan waktu, atau lingkungan, dan atau orang-orang yang menjalaninya). Perlindungan seni ukir melalui Indikasi Geografissangat tergantung pada faktor alam seperti bahan kayu untuk membuat seni ukir dan manusia penghasil yang bersangkutan. Dengan kata lain, perlindungannya tetap berlangsung selama ciri dan/atau kualitas, karakteristik khas yang menjadi dasar diberikannya perlindungan masih ada, dan tidak ada lagi perlindungan ketika karakteristiknya hilang.Namun tidak ada yang dapat memprediksi sampai kapan tanda atau karakteristik khas seni ukir dari masingmasing daerah di Indonesia masih melekat atau justru hilang, karena pada hakikatnya perubahan adalah keniscayaan.

Berikutnya ditinjau dari aspek keberadaan mashlahabmenurut syara, perlindungan seni ukir melalui Indikasi Geografis termasuk kemaslahatan dalam kategori mashlahah al-mursalahyang dalam terminologi ushul fiqh diartikan sebagai memelihara maksud syara' dengan jalan menolak segala yang merusakkan makhluk. Perlindungan tersebut sangat dibutuhkan karena apabila terjadi plagiasi atau kejahatan lain terhadap penggunaan desain seni ukir dalam produksi yang tidak legal, maka tentu merugikan banyak pihak yang jelas-jelas bertentangan dengan cita-cita atau tujuan dari kemaslahatan, yaitu menarik maslahat dan menghilangkan madhorrot(jalbu al-mash $₫ l i h$ dan daf'u al-madhorrot).Selain itu tidak ada dalil syara' yang secara khusus menjadi dasar bentuk dan jenis kemaslahatan terhadap perlindungan seni ukir melalui Indikasi Geografis sehingga kemaslahatan terhadapnya bukan termasuk kategori mashlahah mu'tabarah. Begitu pula,eksistensi perlindungan seni ukir melalui Indikasi Geografis yang ada dalam perundang-undangan tidak bertentangan dengan ketentuan syara' sehingga bukan termasuk kategori mashlahah mulghah.

\section{Simpulan}

Mengacu pada pengertian Indikasi Geografis dalam peraturan di atas, dapat diketahui bahwa secara definitifSeni Ukir bisa dimasukkan ke dalam kategori Indikasi Geografis untuk mendapatkan perlindungan karena seni ukir bisa menjadi tanda yang menunjukkan daerah asal suatu barang. Selain itu, seni ukir merupakan hasil kerajinan yang dibuat oleh manusia, atau yang dalam peraturan tersebut disebut sebagai faktor manusia. Setiap ukiran dari masing-masing daerah memiliki kualitas dan karakteristik tertentu sehingga layak untuk dimintakan perlindungan melalui Indikasi Geografis selama karakteristik khasnya masih melekat.Ciri dan kualitas 
suatu barang yang dipelihara dan dipertahankan dalam jangka waktu tertentu akan melahirkan reputasi (keterkenalan) atas barang tersebut, yang selanjutnya memungkinkan barang tersebut memiliki nilai ekonomi tinggi.

Seni ukir harus dilindungi agar terhindar dari plagiasi dengan didaftarkan untuk memperoleh sertifikat Indikasi Geografis sehingga menimbulkan kemaslahatan. Apabila telah terjadi plagiasi yang pasti membawa madhorot maka secepatnya harus ditindak cepat untuk dicarikan perlindungan karena dalam Islam kemudaratan harus dihilangkan. Hal ini tertuang dalam salah satu kaidah fiqh, yaitu: الضَّرَرْرَزَالَ. Aplikasi kaidah tersebut ialah lebih pada kewajiban menghilangkan mudarat setelah mudarat itu terjadi. Seperti kasus plagiasi yang pernah terjadi terhadap Mebel Ukir Jepara, maka langkah yang harus ditempuh untuk menghilangkan kemudaratan tersebut adalah mencari perlindungan melalui sertifikat Indikasi Geografis.

\section{Daftar Pustaka}

Arfan, Abbas. "Maslahah dan Batasan-Batasannya Menurut Al-Bûthî (Analisis Kitab Dlawâbith al-Mashlahah Fi al-Syarîah al-Islâmiyyah)," de Jure, I. Juni, r - 1 r.

Arfan, Abbas. Kaidah-Kaidah Fiqh Mu'amalah dan Aplikasiny a dalam Ekonomi Islam \& Perbankan Syariah. Jakarta: Direktorat Pendidikan Tinggi Islam Direktorat Jenderal Pendidikan Islam Kementerian Agama Republik Indonesia, r • 1 .

Al-Qur'an Ma'had Tahfidh Yanbu’ul Qư'an, Al-Quddus Al-Quran dan Terjemahannya. Kudus: CV. Mubarokatan Thoyyibah, 2014.

Ash Shiddieqy, Teungku Muhammad Hasbi. Falsafah Hukum Islam. Semarang: PT. Pustaka Rizki Putra, 2001.

Asmawi. Perbandingan Ushul Fiqh. Jakarta: Amzah, 2011.

Dahlan, Abd. Rahman. Ushul Fiqh. Cet. 3. Jakarta: Amzah, 2014.

Effendi,Satria.Ushul Fiqh.(Jakarta: Prenada Media, 2005.

Farisa Adila,"Hak Indikasi Geografis Mebel Ukir Jepara (IG MUJ) dalam Peningkatan Ekonomi Daerah Kabupaten Jepara",(Online), (https://www.academia. edu/10110570/Hak_Indikasi_Geografis_Mebel_Ukir_Jepara_IG_MUJ_ dalam_Peningkatan_Ekonomi_Daerah_Kabupaten_Jepara. Diakses 27 Maret 2016).

Haroen, Nasrun. Ushul Fiqh I. Jakarta: Logos Wacana Ilmu, 1997. 
Hidayah, Khoirul. Tingkat Pemahaman Mahasiswa tentang Perlindungan Hak Cipta Atas Karya Tulis (Studi Terhadap Mahasiswa UIN Maulana Malik Ibrabim Malang). De Jure. Vol. 5 No. : 52-66. 2013.

Hidayah, Khoirul. Hukum Hak Kekayaan Intelektual di Indonesia (Kajian UU dan Integrasi Islam). Malang: UIN Press, 2012.

Ikrar. Paradigma Hukum Islam dan Problematika Penerapannya. Malang: UM Press, 2012.

Jumantoro, Totok dan Samsul Munir Amin. Kamus Ilmu Ushul Fikih. Jakarta: Amzah, 2005.

Sutedi, Adrian. Hak atas Kekayaan Intelektual. Jakarta: Sinar Grafika, 2013.

Syarifuddin, Amir. Ushul Fiqh 2. Jakarta: Kencana, 2014.

Saidin, OK. Aspek Hukum Hak Kekayan Intelektual (Intellectual Property Rights). Jakarta: Raja Grafindo Persada, 2013.

Wahyudi, Ahmad. Rancang Bangun Sistem Informasi Industri Mebel Ukir Jepara BerbasisWeb. Malang: Jurusan Teknik Informatika Fakultas Sains Dan Teknologi Universitas Islam Negeri Maulana Malik Ibrahim, 2010.

Zuhri,Saifudin.Ushul Figih Akal Sebagai Sumber Hukum Islam. Yogyakarta: Pustaka Pelajar, 2011.

Peraturan Perundang-Undangan

Peraturan Pemerintah Nomor 51 Tahun 2007 Tentang Indikasi Geografis

Undang-Undang No. 15 tahun 2001 tentang Merek 